\title{
Al-Madãris
}

VOL. 2, NO. 1, 2021

E-ISSN: 2745-9950

https://journal.staijamitar.ac.id/index.php/almadaris

\section{KONSERVASI SUMBER DAYA ALAM DALAM PERSPEKTIF ISLAM}

\author{
Muhammad Syariful Anam \\ Institut Agama Islam Negeri (IAIN) Salatiga \\ syarifulanam2700@gmail.com \\ Wina Yulianti \\ Institut Agama Islam Negeri (IAIN) Salatiga \\ winaylynti20@gmail.com \\ Sari Nur Safitri \\ Institut Agama Islam Negeri (IAIN) Salatiga \\ sarinursafitri24@gmail.com \\ Siti Nur Qolifah \\ Institut Agama Islam Negeri (IAIN) Salatiga \\ nurkholifah.febi@gmail.com \\ Rina Rosia \\ Institut Agama Islam Negeri (IAIN) Salatiga \\ rinarosia@iainsalatiga.ac.id
}

\begin{abstract}
This study examines how Islam views natural resource conservation. This is a qualitative research with a descriptive approach. Based on the results of the studies that have been carried out, it can be concluded that Islam teaches humans to be responsible for all of Allah's creation, including being responsible for protecting and maintaining natural resource ecosystems. The principle of conservation in Islam is based on mutual care between humans and nature, because basically humans take advantage of the available natural resources. In addition, in the utilization of natural resources, humans must pay attention to balance, not be exploitative and remain proportional so that natural resources are preserved.
\end{abstract}

Keywords: Islam, Conservation, Natural Resources

$\overline{\text { Al-Madãris, Volume 2 (1), } 2021}$ 


\section{A. Pendahuluan}

Sumber daya alam adalah hal urgent bagi kelangsungan hidup manusia. Sumber daya alam memberikan banyak manfaat bagi kehidupan, baik berupa sumber energi ataupun untuk memenuhi kebutuhan manusia. Menurut Qur'an (2017), pemanfaatan sumber daya alam dimaksudkan untuk kemakmuran rakyat dengan tetap memperhatikan kelestarian fungsi dari lingkungan hidupnya. Dalam hal ini, sumber daya alam mempunyai peran ganda, yaitu sebagai modal pertumbuhan ekonomi dan penopang sistem kehidupan. Dengan adanya fungsi ganda tersebut, pengelolaan sumber daya alam senantiasa harus seimbang untuk menjamin keberlanjutan dalam pembangunan nasional. Sumber daya alam ini dapat ditemukan di mana saja seperti di dalam tanah, permukaan tanah, udara, air dan sebagainya. Yang mana sumber daya alam tersebut ada yang dapat diperbaharui (renewable resources) maupun yang tidak dapat diperbaharui (non renewable resources).

Tersedianya sumber daya alam yang melimpah merupakan rahmat karunia yang diberikan oleh Tuhan untuk seluruh makhluk hidup. Khususnya, manusia sebagai khalifah dituntut untuk mengupayakan alam dan lingkungan agar selalu seimbang, baik dalam pemanfaatan dan pelestariannya. Sebagaimana dalam AlQuran surat Al-A'raf ayat 56 yang mengingatkan agar manusia menjaga kelestarian lingkungan hidup.

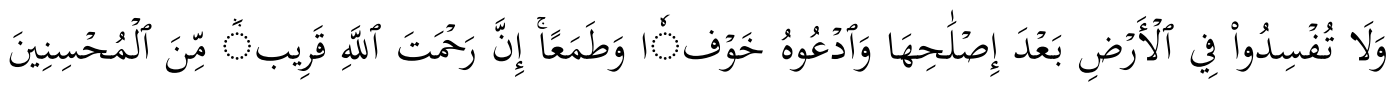

07

Artinya: "Dan janganlah kamu membuat kerusakan di muka bumi, sesudah (Allah) memperbaikinya dan berdoalah kepada-Nya dengan rasa takut (tidak akan diterima) dan harapan (akan dikabulkan). Sesungguhnya rahmat Allah amat dekat kepada orang-orangyang berbuat baik."

Islam telah memberi amanat kepada manusia agar tidak membuat kerusakan terhadap sumber daya yang ada di lingkungan. Tetapi pada kenyataannya, kegiatan yang dilakukan manusia belakangan ini mengarah kepada eksploitasi tanpa adanya pembaruan atau regenerasi. Meskipun dalam hal ini lingkungan dapat melakukan regenerasinya sendiri, namun perlu diingat bahwa lingkungan memiliki daya regenerasi yang terbatas. Selama penggunaan atau eksploitasi sumber daya alam dilakukan di bawah batas daya regenerasinya, maka sumber daya alam terbaharui dapat digunakan secara berkepanjangan. Akan tetapi apabila melebihi batasnya, maka sumber daya akan mengalami kerusakan dan fungsinya sebagai faktor produksi maupun faktor konsumsi atau sebagai sarana pelayanan akan terganggu (Cholili, 2016).

Menurut Keraf (2010) dalam Efendi (2011), Islam mengajarkan manusia untuk anti terhadap sikap antroposentris dalam pemanfaatan sumber daya alam. Sikap antroposentris merupakan suatu sikap yang menganggap manusia sebagai pusat dari sistem alam semesta. Dalam ajaran antroposentrisme menganggap bahwa manusia beserta kepentingannya inilah yang paling menentukan dalam tatanan ekosistem dan kebijakan yang diambil dalam hubungannya secara 
langsung maupun tidak langsung dengan alam. Sikap antroposentris dapat mengakibatkan gaya hidup manusia yang mewah dan cenderung konsumtif. Gaya hidup seperti inilah yang menjadi penyebab eksploitasi berlebihan terhadap sumber daya alam yang berimbas pada kerusakan lingkungan hidup. Hal ini bertentangan dengan ajaran Islam, bahwa manusia senantiasa diperintahkan untuk hidup sederhana dan menghemat dalam menggunakan sumber daya alam.

Upaya pemanfaatan sumber daya alam perlu dilengkapi dengan pemahaman dan penguasaan teknik pengelolaan yang tepat agar tidak menyebabkan kerusakan lingkungan (Saroinsong \& Kalangi, 2016). Oleh karena itu, penting untuk melakukan pembekalan dan pengkayaan ilmu dan teknologi pengelolaan sumber daya alam yang berasas konservasi terhadap masyarakat. Hal ini dilakukan agar sumber daya alam tetap lestari walaupun banyak diambil manfaatnya. Dengan demikian, penelitian ini akan membahas terkait konservasi sumber daya alam dalam perspektif Islam.

\section{B. Review Literatur}

Berdasarkan arti leksikal, konservasi diartikan sebagai pelestarian, pengelolaan, serta memelihara sumber daya alam dan kultural (Cholili, 2016). Sementara itu, Campbell (1997) dalam Cholili (2016) memberikan definisi mengenai konservasi menjadi tiga arti, yaitu: pertama, perlindungan sumber daya alam; kedua, memanfaatkan sumber daya dengan menggunakan akal (intellect utilization); dan ketiga, penggunaan sumber daya alam secara bijaksana. Atau konservasi juga dapat diartikan sebagai upaya menjaga kelestarian alam demi kelangsungan hidup umat manusia (Maslihatin \& Fauzy, 2016).

Sedangkan menurut Undang-Undang No. 32 Tahun 2009 Tentang Perlindungan Dan Pengelolaan Lingkungan Hidup, konservasi sumber daya alam adalah pengelolaan sumber daya alam untuk menjamin pemanfaatnyannya secara bijaksana serta kesinambungan ketersediaannya dengan tetap memelihara dan meningkatkan kualitas nilai serta keanekaragamannya. Konservasi dapat dilihat dari dua aspek, yaitu aspek ekonomi dan ekologi. Dari aspek ekonomi, berarti berusaha mengalokasikan sumber daya alam untuk saat ini, sedangkan dari aspek ekologi, konservasi berarti mengalokasikan sumber daya untuk masa mendatang (Christanto, 2014). Dalam upaya konservasi, dapat dilakukan beberapa tindakan diantaranya (Maslihatin \& Fauzy, 2016):

1. Melakukan pengambilan sumber daya alam secara terbatas.

2. Mengeksploitasi sumber daya alam secara efisien.

3. Mengembangkan sumber daya alternatif untuk menggantikan sumber daya yang jumlahnya terbatas.

4. Menggunakan unsur-unsur teknologi yang ramah lingkungan.

5. Meminimalisasi dan mengatasi pencemaran lingkungan guna menyelamatkan cadangan sumber daya alam.

Koservasi sendiri penting untuk dilakukan guna melindungi sumber daya alam agar terus dapat dinikmati dalam jangka waktu yang lebih panjang. Di samping itu, konservasi juga dimaksudkan untuk menyelamatkan keberlangsungan sumber daya alam yang sering dikaitkan dengan upaya pembangunan berkelanjutan. Dimana pembangunan berkelanjutan tersebut 
sering diuraikan sebagai perbaikan kualitas hidup yang disesuaikan dengan daya dukung lingkungan (carrying capacity) (Fauzi \& Oxtavianus, 2014).

Dalam Islam, perintah konservasi telah muncul sejak zaman Nabi Adam a.s. yang kemudian diikuti oleh para nabi hingga kemudian sampai kepada Nabi Muhammad SAW. Menurut Islam, ada atau tidaknya persoalan lingkungan/sumber daya alam, kegiatan konservasi harus terus dikerjakan dengan tekun dan konsisten (Sundari, 2019).

Konservasi alam dalam Islam diajarkan oleh Nabi Muhammad SAW melalui perancangan konsep hima', yaitu kawasan yang tidak boleh digunakan oleh penduduk terutama untuk kepentingan yang bersifat eksploitatif (Ubaidillah, 2010). Artinya, kawasan tersebut merupakan kawasan yang dilindungi oleh pemerintah Islam atas dasar syariat dan dalam rangka melindungi serta melestarikan alam (Maslihatin \& Fauzy, 2016). Jika direfleksikan bahwa sesungguhnya apa yang dilakukan oleh Nabi pada masa itu merupakan konsep berpikir jangka panjang mengenai pelestarian lingkungan hidup. Oleh karena itu, dalam ajaran Islam sebenarnya mengandung basic framework etika konservasi alam dan lingkungan yang relevan.

Menurut Utami (2008) dalam Maslihatin \& Fauzy (2016), aktivitas konservasi yang pernah dilakukan oleh Nabi Muhammad SAW dan para sahabat serta ayat-ayat Al-Qur'an sebagai pedomannya memiliki beberapa konsep konservasi antara lain:

1. Menjaga keseimbangan jiwa.

2. Menjaga siklus hidrologi (air).

3. Menjaga kestabilan udara.

4. Reboisasi.

5. Menjaga kawasan penambangan.

Sementara itu, konservasi sumber daya alam dan lingkungan juga merupakan tujuan syariat (maqashid syariah) yang utama. Tujuan syariat tersebut terformulasikan dalam lima kemaslahatan dasar (al-kulliyat al-khamsah) yang menjadi tegaknya kehidupan manusia, yaitu; hifzal-din (perlindungan agama), hifz al-nafs (perlindungan jiwa), hifz al-nasl (perlindungan keturunan), hifz al-'aql (perlindungan akal) dan hifz al-mal (perlindungan harta). Jika dikorelasikan antara konsep al-kulliyat al-khamsah dengan konservasi lingkungan, artinya melindungi lingkungan sama halnya dengan melindungi agama, jiwa, keturunan, akal dan harta (Ubaidillah, 2010).

\section{Metodelogi}

Penelitian ini merupakan penelitian kualitatif dengan menggunakan pendekatan deskriptif. Pendekatan deskriptif, umumnya lebih menekankan pada aspek kajian yang lebih mendalam terhadap suatu masalah dan tidak mengeneralisasi suatu permasalahan (Siyoto \& Sodik, 2015). Sedangkan penelitian deskriptif sendiri bertujuan untuk mendeskripsikan suatu fenomena dan karakteristiknya (Nassaji, 2015).

Berikutnya, penelitian ini menggunakan data sekunder sebagai data utama. Data sekunder yaitu data yang didapatkan secara tidak langsung, misalnya melalui media perantara atau dokumen (Hardani et al., 2020). Pada umumnya, 
data sekunder berupa arsip catatan atau laporan tersusun (data yang bersifat dokumentasi) baik yang dipublikasikan ataupun tidak.

Dalam penelitian ini, metode pengumpulan data dilakukan dengan beberapa metode, diantaranya metode kepustakaan, dokumentasi dan intuitif subjektif. Metode kepustakaan sendiri memanfaatkan sumber literatur yang relevan untuk memperoleh data penelitian (Zed, 2008). Sedangkan, metode dokumentasi dilakukan dengan mencatat data yang sudah ada dalam dokumen atau arsip (Agam, 2015). Sementara, intuitif subjektif yaitu pelibatan pendapat penulis terhadap masalah yang sedang dikaji (Ariyanti et al., 2014).

Selanjutnya, proses analisis data yang dilakukan dalam penelitian ini terjadi secara bolak-balik dan interaktif yang diawali dengan mengumpulkan data (data collection). Setelah data terkumpul, data kemudian direduksi (data reduction). Setelah itu, proses penyajian data (display data), dan tahap terakhir yaitu memaparkan dan membuat kesimpulan (Ariyanti et al., 2014).

\section{Hasil Penelitian dan Pembahasan}

\section{Definisi Sumber Daya Alam}

Segala sesuatu yang terdapat di luar maupun di dalam yang memiliki potensi serta belum berperan dalam proses produksi disebut dengan sumber daya alam (Pongtuluran, 2015). Menurut Soerinegara, semua yang ada di alam sekitar kita adalah lingkungan. Sedangkan komponen-komponen pembentuk alam, seperti biotik dan abiotik yang dapat digunakan dalam memenuhi kebutuhan hidup manusia adalah sumber daya alam (Qur'an, 2017). Unsur biotik berupa makhluk hidup yang terdiri atas tumbuhan, hewan, dan mikroorganisme. Sementara untuk unsur abiotik merupakan makhluk tak hidup seperti sinar matahari, angin, tanah, air termasuk juga minyak bumi dan barang tambang (Giyarto, 2015).

Secara universal, sumber daya alam adalah segala sesuatu yang dianggap mempunyai nilai kegunaan (Fauzi, 2006). Sumber daya alam juga dapat diartikan tersedianya barang dan jasa dalam suatu komponen ekosistem yang bermanfaat bagi manusia (Qur'an, 2017). Nilai ekonomi dalam konsep sumber daya erat kaitannya dengan proses produksi. Pernyataan itu sejalan dengan pandangan Adam Smith yang mengatakan bahwa semua keluaran yang dihasilkan akan membutuhkan faktor produksi (Purba et al., 2020).

Menurut Rees (1990) dalam Purba et al. (2020), dalam terdapat dua kriteria dalam sumber daya alam, pertama, bahwa harus adanya pengetahuan, teknologi, dan keterampilan dalam menggunakannya. Kedua, harus adanya kebutuhan terkait dengan sumber dayanya. Tidak hanya dua kriteria itu saja, sumber daya alam juga memiliki dua standar aspek, yakni aspek teknis tentang proses pemanfaatan sumber daya dan aspek kelembagaan tentang siapa saja yang berhak dalam mengendalikan sumber daya dan penggunaan teknolonginya.

Sederhananya, pengertian sumber daya erat kaitannya dengan kegunaan (kemanfaatan), baik untuk masa kini maupun masa yang akan datang dalam memenuhi kebutuhan dan kesejahteraan hidup manusia (Purba et al., 2020). Menurut Reksodipradjo (1990) dalam Umar \& Dewata (2020), sumber daya alam adalah sesuatu yang memiliki nilai kegunaan dalam keadaan pada saat ditemukan. Sumber daya alam meliputi atas segala yang terdapat di bumi, bisa 
benda hidup maupun mati yang bermanfaat bagi manusia yang jumlahnya terbatas dan pendayagunaan/pemeliharaannya memenuhi standar teknologi, ekonomi, sosial dan lingkungan.

Adanya inovasi teknologi, kemajuan peradaban, dan bertambahnya populasi manusia menyebabkan terjadinya ekspolitasi sumber daya alam. Hal ini akan berakibat pada menipisnya persediaan sumber daya alam secara perlahan (Laksana, 2017). Maka, seharusnya masyarakat harus lebih bijaksana serta memiliki kesadaran tinggi dalam memanfaatkan sumber daya alam dengan selalu menjaga keserasian dan keseimbangannya.

\section{Macam-Macam Sumber Daya Alam}

Terdapat beberapa macam pengklasifikasian sumber daya alam. Berikut adalah pengklasifikasian sumber daya alam berdasarkan jenis, habitat, sifat, nilai, dan potensi penggunaannya (Giyarto, 2015):

a. Berdasarkan jenisnya

Berdasarkan jenisnya, sumber daya alam dibedakan menjadi dua yaitu hayati dan non hayati. Sumber daya alam hayati berupa makhluk hidup atau sumber daya biotik, seperti tumbuhan, binatang dan mikroorganisme. Sedangkan sumber daya nonhayati berupa benda-benda mati atau abiotik yang terdiri atas air, bahan tambang, tanah, dan sebagainya (Qur'an, 2017).

b. Berdasarkan habitatnya

Berdasarkan habibatnya, sumber daya alam terdiri atas terestris dan akuatik. Terestris adalah semua cadangan alam yang berasal dari daratan yang berhubungan dengan tanah dan pemanfaatannya. Lalu, akuatik adalah cadangam alam yang berasal dari daerah perairan yang berhubungan air dan pemanfaatannya (Giyarto, 2015).

c. Berdasarkan sifat

Berdasarkan sifatnya sumber daya alam dibagi menjadi 3, yaitu (Umar \& Dewata, 2020):

1) Sumber daya alam yang dapat diperbaharui (renewable resources), jenis ini mampu melakukan pengembangbiakan dan regenerasi (dapat dipulihkan kembali), contohnya air, tumbuhan, binatang, mikroba, dan tanah.

2) Sumber daya alam yang tak dapat diperbaharui (nonrenewable resources), memiliki cadangan yang terbatas. Misalnya, barang tambang, gas bumi, dan minyak bumi.

3) Sumber daya alam yang tidak habis pakai, contohnya matahari, udara, air dalam siklus hidrologi, pasang surut air laut, dan energi gelombang laut.

d. Berdasarkan nilai

Sumber daya alam dibedakan menjadi sumber daya alam ekonomis tinggi, ekonomis rendah, dan nonekonomis. Sumber daya alam ekonomis tinggi, seperti emas, intan, dan perak. Sumber daya alam nilai rendah, yaitu seperti barang untuk bangunan (batu dan pasir). Sementara itu, sumber daya alam nonekonomis meliputi udara dan matahari, yang mana kita tidak membutuhkan biaya untuk mendapatkannya (Giyarto, 2015).

e. Berdasarkan potensi penggunaannya (Qur'an, 2017) 
1) Sumber daya alam materi yang digunakan bentuk fisiknya. Contohnya, emas, kayu, batu, besi dan lain-lain.

2) Sumber daya alam energi yang dimanfaatkan energinya. Contohnya, minyak bumi, matahari, air terjun, pasang surut air laut, dan lain-lain.

3) Sumber daya alam ruang yang berupa ruang atau tempat hidup. Contohnya, jagat raya dan daratan.

\section{Konservasi Sumber Daya Alam dan Pembangunan Berkelanjutan}

Konservasi dari kata conservation yang terdiri atas kata con (together) dan servare (save) yang mempunyai pengertian mengenai upaya dalam pendayagunaan segala sesuatu yang kita miliki secara cermat dan hati-hati (wise use) (Winarti, 2018). Menurut Undang-Undang No. 5 Tahun 1990 Tentang Konservasi Sumber Daya Alam Hayati Dan Ekosistemnya, konservasi diartikan sebagai upaya pengelolalaan sumber daya alam secara bijaksana yang berpedoman pada asas pelestarian agar tetap serasi dan seimbang. Konservasi merupakan pengaturan pemanfaatan biosfer oleh manusia yang memperoleh hasil yang berkelanjutan bagi kehidupan sekarang dengan selalu menjaga potensi untuk kebutuhan yang akan datang, serta menjaga keberadaannya secara berkesinambungan baik dari mutu maupun jumlah (Damanik, 2019).

Konservasi dalam makna sebenarnya memuat konsep perlindungan (preservation) serta pengembangan (development) cadangan alam dan energi untuk keperluan masa sekarang dan masa yang akan datang (Nugroho, 2020). Terdapat tujuan dari konservasi diantaranya (1) merealisasikan kelestarian dan keseimbangan sumber daya hayati beserta keanekaragaman komunitas organiknya yang mana dapat membantu dalam meningkatkan kesejahteraan dan kualitas manusia, (2) menjaga pemanfaatan sumber daya secara serasi dan seimbang (Rachman, 2012).

Pengertian lain yang terdapat dalam Undang-Undang No. 32 Tahun 2009 Tentang Perlindungan Dan Pengelolaan Lingkungan Hidup, konservasi sumber daya alam adalah pengelolaan sumber daya alam untuk menjamin pemanfaatnyannya secara bijaksana serta kesinambungan ketersediaannya dengan tetap memelihara dan meningkatkan kualitas nilai serta keanekaragamannya. Sementara itu, menurut Abdullah (2010) dalam Cholili (2016), konservasi sumber daya alam adalah sebuah tindakan nyata atas komunikasi persuasif dalam penanggulangan krisis lingkungan.

Dalam implementasinya, konservasi memuat 7 (tujuh) kriteria yang menampilkan tujuan dasar pemanfataan sumber daya alam dan lingkungan. Ketujuh kriteria tersebut adalah (Fandeli, 2012):

a. Proteksi.

b. Restorasi.

c. Pemanfataan secara bijaksana.

d. Substitusi.

e. Maksimalisasi proses.

f. Reduce (mengurangi), reused (menggunakan kembali), recycle (memproses kembali), dan recovery (pemulihan).

g. Integration (Keselarasan dalam pemenuhan antar makhluk hidup). 
Salah satu tujuan dari konservasi adalah untuk memastikan kebutuhan sumber daya alam agar dapat dirasakan oleh generasi yang akan datang. Artinya konservasi merupakan upaya untuk melakukan pembangunan yang berkelanjutan. Gobinath et al. (2010) memberikan pernyataan bahwa keberlanjutan merupakan waktu yang dibutuhkan bagi negara untuk menyediakan lingkungan yang lebih bersih dan aman bagi generasi di masa depan. Lebih jauh, Otto \& Wohlpart (2009) mengungkapkan bahwa keberlanjutan melibatkan manusia untuk menemukan kesimbangan antara manusia dengan lingkungan dan alam semesta.

Menciptakan lingkungan yang bersih dan menjaga keseimbangan alam, dapat dicapai dengan melakukan konservasi. Melalui semangat dan jiwa konservasi, diharapkan manusia bisa lebih bijaksana dalam melihat serta memperhatikan kelanjutan kehidupan di bumi dan berusaha memperbaiki keadaan alam yang telah rusak. Oleh karena itu, konservasi wajib dilakukan apabila manusia masih ingin menghirup udara bersih, meminum air dari sumber yang bersih dan menikmati panorama yang eksotis.

\section{Konservasi Sumber Daya Alam Dalam Islam}

Islam memandang alam semesta sebagai nikmat yang diberikan Allah SWT. Oleh karena itu, Allah melimpahkan segala kebutuhan manusia dari tanah, air, udara, baik yang ada di dalam maupun di atas bumi agar dapat dimanfaatkan dengan baik oleh manusia. Di sisi lain, sumber daya alam ini hanyalah amanah atau titipan yang mana manusia bukanlah pemilik hakiki atas alam semesta, sebagaimana QS. Al-Ahzab ayat 72. Sehingga manusia harus memelihara dan mengelola sumber daya alam dengan penuh kehati-hatian serta tanggung jawab.

Sebagai Khalifah fil Ard', manusia berperan sebagai makhluk yang diberi akal untuk menjaga dan memelihara sumber daya alam sebagai tempat tinggal makhluk Allah. Menurut Nafisah (2017), mengharmoniskan manusia dengan sumber daya alam adalah sebuah keniscayaan. Dalam upaya harmonisasi manusia dengan linkungan hidup dapat dilakukan dengan beberapa cara, pertama, upaya pengintegrasian manusia dengan sumber daya alam. Kedua, memahami hakikat alam semesta adalah sama-sama ciptaan Allah dimana tidak ada hak untuk merasa lebih unggul. Ketiga, bagaimana manusia menghormati keberadaan alam semesta sebagai makhluk ciptaan Allah yang tidak pantas untuk dieksploitasi atau dirusak.

Sumber daya alam memiliki peran ganda, yaitu sebagai penopang sistem kehidupan (life support system) dan modal pertumbuhan ekonomi (resource-based economy). Maka dari itu, sumber daya alam harus dikelola dengan baik (Qur'an, 2017). Di lain sisi, muncul berbagai permasalahan yang mengakibatkan terjadinya kerusakan sumber daya alam, sehingga dikhawatirkan berdampak buruk bagi kehidupan makhluk di bumi ini. Problem kerusakan sumber daya alam ini tidak terlepas dari perbuatan manusia baik sengaja maupun tidak disengaja telah berbuat kerusakan dalam upaya meningkatkan kualitas hidupnya. Islam telah menjelaskan akibat kerusakan sumber daya alam yang disebabkan karena ulah manusia, dalam QS. Ar-Ruum ayat 4l:

$\overline{\text { Al-Madaris, Volume 2 (1), } 2021}$ 


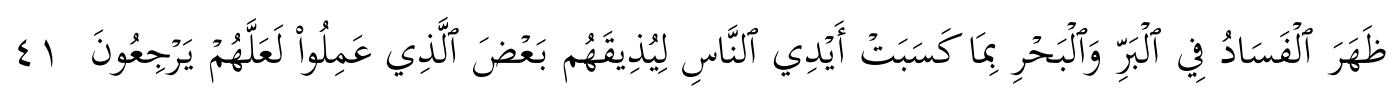

Artinya: "Telah nampak kerusakan di darat dan di laut disebabkan karena perbuatan tangan manusia, supaya Allah merasakan kepada mereka sebahagian dari (akibat) perbuatan mereka, agar mereka kembali (ke jalan yang benar)".

Dalam ayat tersebut dijelaskan telah terjadi perusakan oleh perbuatan manusia. Allah menjadikan kerusakan-kerusakan itu supaya manusia merasakan akibat perbuatannya agar mereka sadar dan kembali ke jalan yang benar.

Konservasi sumber daya alam merupakan suatu upaya dalam menjaga dan memelihara atas apa yang telah dititipkan Allah kepada manusia, yang mana pada dasarnya manusia turut mengambil manfaat dari sumber daya alam yang tersedia. Cholili (2016) mendefinisikan konservasi sebagai upaya pengelolaan dan pemanfaatan sumber daya alam secara alami, berkelanjutan dan teratur baik sumber daya biotik maupun non biotik dengan melindungi proses-proses interaksi antar makhluk hidup dalam upaya mempertahankan keanekaragaman hayati. Pengelolaan dan pemanfaatan sumber daya alam harus memperhatikan kelestarian dan aspek sosial. Sebagaimana difirmankan dalam QS. Al-A'raf ayat 56 yang artinya "Dan janganlah kamu membuat kerusakan di muka bumi, sesudah (Allah) memperbaikinya dan berdoalah kepada-Nya dengan rasa takut (tidak akan diterima) dan harapan (akan dikabulkan). Sesungguhnya rahmat Allah amat dekat kepada orang-orang yang berbuat baik".

Menurut Efendi (2011), setidaknya terdapat bentuk perlindungan terhadap sumber daya alam:

a. Perlindungan terhadap tanah

Telah dijelaskan Dalam Al-Qur'an Surat Yasin ayat 34-35:

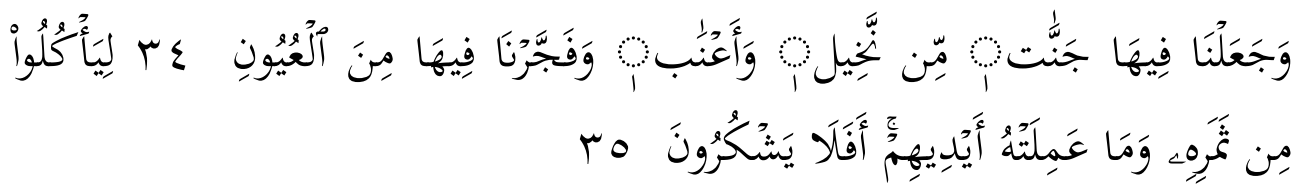

Artinya: "Dan Kami jadikan padanya kebun-kebun kurma dan anggur dan Kami pancarkan padanya beberapa mata air, supaya mereka dapat makan dari buahnya, dan dari apa yang diusahakan oleh tangan mereka. Maka mengapakah mereka tidak bersyukur?".

Allah menciptakan bumi (tanah) adalah untuk kemanfaatan bagi makhluk-Nya. Dijadikan-Nya tanah sebagai tempat tumbuhnya tumbuhtumbuhan dan tempat tinggal manusia dengan segala aktivitasnya. Maka sebagai bentuk rasa syukur atas nikmat-Nya adalah dengan menjaganya.

b. Perlindungan terhadap air

Air merupakan sumber daya alam yang sangat penting dan vital. Dua pertiga dari bumi ini berupa air, air merupakan cikal bakal dari kehidupan.

c. Perlindungan terhadap hewan dan tumbuhan

Hewan dan tumbuhan merupakan komponen penting dalam sumber daya alam. Tumbuhan memiliki peran penting dan vital sebagai sumber 
makanan, pemasok oksigen, penghalang bencana, dan lain-lain. Begitu pula hewan, masing-masing memiliki peran penting dalam kestabilan ekosistem.

\section{Menjaga Keseimbangan Alam}

Manusia merupakan bagian dari alam, artinya menjaga keseimbangan alam merupakan suatu keharusan. Tidak jarang manusia telah lupa bahwa mereka membutuhkan sumber daya alam, sehingga dalam pemanfaatannya sering dieksploitasi dan tidak memikirkan dampaknya (Wulandari, 2016).

Saat ini sudah banyak terjadi bencana alam yang diakibatkan oleh kerusakan lingkungan. Kerusakan lingkungan dapat terjadi karena faktor alami dan faktor aktivitas manusia. Faktor alami berasal dari fenomena alam yang tidak menentu seperti cuaca ekstrim, perubahan iklim yang menyebabkan bencana alam seperti gunung meletus dan tsunami. Sedangkan, faktor aktivitas manusia berasal dari pengambilan sumber daya alam yang tidak ramah lingkungan seperti penebangan hutan.

Keseimbangan ekosistem akan terjadi apabila komponen dalam jumlah berimbang. Komponen ekosistem mencakup: faktor biotik, abiotik, produsen, konsumen, detritivore, dan dekomposer (lagi menjadi faktor abiotik, pengurai). Komponen tersebut saling berinteraksi dan saling membutuhkan.

Awal mula diciptakan sumber daya alam adalah faktor abiotik yang mana sebagai penyokong tumbuhnya tumbuh-tumbuhan, kemudian tumbuhan sebagai sumber kehidupan konsumen maupun detritivore (binatang dan manusia), yang pada akhirnya diurai menjadi zat-zat organik, hal ini terjadilah proses daur ulang yang seimbang (Jumhana, 2006).

Keterlibatan manusia sangat memengaruhi ekosistem. Kemajuan teknologi dan ilmu pengetahuan yang tidak terkendali menyebabkan ketidaksemimbangan ekosistem. Dibutuhkan kebijaksanaan manusia dalam memanfaatkan sumber daya alam. Pemanfaatan sumber daya alam yang baik akan berdampak pada kebermanfaatan sumber daya alam kepada manusia dan makhluk lainnya. Begitu pula merusak alam akan berdampak pada kerugian manusia dan makhluk lainnya. Oleh karena itu, menjaga keseimbangan alam merupakan hal yang penting dan diperlukan kesadaran dari setiap individu.

\section{E. Kesimpulan}

Tujuan dilakukannya konservasi sumber daya alam ialah untuk menyelamatkan serta melestarikan alam dan lingkungan agar manfaatnya dapat terus dirasakan dalam jangka waktu yang lebih panjang. Tujuan tersebut erat kaitannya dengan konsep pembangunan berkelanjutan yaitu pola pembangunan yang tetap memperhatikan dan menjaga keseimbangan sumber daya alam. Artinya segala bentuk aktivitas pengelolaan sumber daya alam harus dilakukan secara proporsional dan tidak melakukan eksploitasi secara berlebihan. Hal tersebut sejalan dengan konsep konservasi dalam Islam, dimana Islam juga mengajarkan kepada manusia untuk selalu berbuat kebaikan dan tidak melakukan perusakan di muka bumi (termasuk sumber daya alam), sebagaimana dijelaskan dalam QS. Al-A'raf ayat 56. Melakukan pemanfaatan sumber daya alam dengan cara-cara yang baik, akan berdampak baik pula terhadap manusia dan makhluk lainnya. Sedangkan jika melakukannya dengan cara merusak, maka akan 
menimbulkan kerugian dan efek negatif terhadap manusia dan makhluk lainnya. Sehingga, dalam melakukan pengelolaan sumber daya alam harus seimbang dan bijaksana.

\section{BIBLIOGRAFI}

Agam, R. (2015). Menulis Karya Ilmiah. Yogyakarta: Familia.

Ariyanti, M., Farandy, A. R., \& Marwan, F. B. (2014). Center of Indonesian Sharia Investment (CISI) sebagai Upaya Peningkatan dan Penguatan Perekonomian Indonesia dalam Arus Bebas Investasi AEC 2015 (Studi Kasus Kecamatan Bandungan Kabupaten Semarang).

Cholili, M. S. (2016). Konservasi Sumberdaya Alam Dalam Islam Sebagai Wujud Pendidikan dan Akhlaq Manusia terhadap Lingkungan. Modeling: Jurnal Program Studi PGMI, 3(1), 74-86.

Christanto, J. (2014). Ruang Lingkup Konservasi Sumber Daya Alam dan Lingkungan.

Damanik, S. E. (2019). Buku Ajar Pengelolaan Sumber Daya Alam dan Lingkungan. Ponorogo: Uwais Inspirasi Indonesia.

Efendi. (2011). Perlindungan Sumber Daya Alam dalam Islam. Kanun: Jurnal Ilmu Hukum, 13(3), 17-31.

Fandeli, C. (2012). Bisnis Konservasi: Pendekatan Baru dalam Pengelolaan Sumberdaya Alam dan Lingkungan Hidup. Yogyakarta: Gadjah Mada University Press.

Fauzi, A. (2006). Ekonomi Sumber Daya Alam dan Lingkungan: Teori dan Aplikasi. Jakarta: Gramedia Pustaka Utama.

Fauzi, A., \& Oxtavianus, A. (2014). Pengukuran Pembangunan Berkelanjutan di Indonesia. Mimbar: Jurnal Sosial Dan Pembangunan, 30(1), 42-52.

Giyarto. (2015). Sumber Daya Alam dan Pemanfaatannya. Klaten: Saka Mitra Kompetensi.

Gobinath, R., Rajeshkumar, K., \& Mahendran, N. (2010). Environmental performance studies on educational institutions. International Journal of Environmental Sciences, 1(1), 18-29.

Hardani, Andriani, H., Ustiawaty, J., Utami, E. F., Istiqomah, R. R., Fardani, R. A., Sukmana, D. J., \& Auliya, N. H. (2020). Metode Penelitian Kualitatif \& Kuantitatif. Yogyakarta: CV. Pustaka Ilmu Group.

Jumhana, N. (2006). Konsep Dasar Biologi. Bandung: UPI Press.

Laksana, A. (2017). Ensiklopedia Sumber Daya Alam Indonesia. Yogyakarta: KhazanahPedia.

Maslihatin, M. Z., \& Fauzy, M. Q. (2016). Konservasi Sumberdaya Alam Tambang Marmer Dalam Tinjauan Perspektif Islam (Studi Kasus PT. Industri Marmer Indonesia Tulungagung Kecamatan Besuki). Jurnal Ekonomi Syariah Teori Dan Terapan, 3(11), 915-927.

Nafisah, M. (2017). Al-Qur'an dan Konservasi Lingkungan (Suatu Pendekatan Maqashid alSyari'ah). Tesis. UIN Syarif Hidayatullah Jakarta.

Nassaji, H. (2015). Qualitative and descriptive research: Data type versus data analysis. Language Teaching Research, 19(2), 129-132.

Nugroho, S. S. (2020). Hukum Konservasi Sumber Daya Alam \& Keanekaragaman Hayati: Sebuah Dilema Antara Potensi \& Ancaman Kepunahan. Klaten: Penerbit Lakeisha.

Al-Madãris, Volume 2 (1), 2021 
Otto, E., \& Wohlpart, A. J. (2009). Creating a Culture of Sustainability: Infusing Sustainability into the Humanities. Journal of Education for Sustainable Development, 3(2), 231-235.

Pongtuluran, Y. (2015). Manajemen Sumber Daya Alam dan Lingkungan. Yogyakarta: Penerbit ANDI.

Purba, B., Nainggolan, L. E., Siregar, R. T., Chaerul, M., Simarmata, M. M., Bachtiar, E., Rahmadana, M. F., Marzuki, I., \& Meganingratna, A. (2020). Ekonomi Sumber Daya Alam: Sebuah Konsep, Fakta dan Gagasan. Yayasan Kita Menulis.

Qur'an, A. A. (2017). Sumber Daya Alam Dalam Pembangunan Berkelanjutan Perspektif Islam. El-Jizya: Jurnal Ekonomi Islam, 5(1), 1-24.

Rachman, M. (2012). Konservasi Nilai dan Warisan Budaya. Indonesian Journal of Conservation, 1(1), 30-39.

Saroinsong, F. B., \& Kalangi, J. I. (2016). Teknik Pengelolaan Sumber Daya Alam untuk Konservasi di Area Pemukiman. Abdimas: Jurnal Pengabdian Kepada Masyarakat, 9(1), 25-34.

Siyoto, S., \& Sodik, M. A. (2015). Dasar Metodologi Penelitian. Yogyakarta: Literasi Media Publishing.

Sundari, I. (2019). Konsep Konservasi Flora dan Fauna Dalam Al-Qur'an (Studi Analisis Tafsîr Asy-Sya'râwi Karya Muhammad Mutawalli Asy-Sya'rawi). Skripsi. Institut Ilmu Al-Qur'an Jakarta.

Ubaidillah, M. H. (2010). Fiqh al-Biah (Formulasi Konsep al-Maqasid al-Shari'ah dalam Konservasi dan Restorasi Lingkungan). Al-Qanun: Jurnal Pemikiran Dan Pembaharuan Hukum Islam, 13(1), 26-52.

Umar, I., \& Dewata, I. (2020). Pengelolaan Sumber Daya Alam. Yogyakarta: Penerbit Deepublish.

Undang-Undang No. 32 Tahun 2009 Tentang Perlindungan dan Pengelolaan Lingkungan Hidup.

Undang-Undang No. 5 Tahun 1990 Tentang Konservasi Sumber Daya Alam Hayati Dan Ekosistemnya.

Winarti. (2018). Mengenal Bentuk-bentuk Konservasi Alam. Klaten: Cempaka Putih.

Wulandari, R. (2016). Metode Kunjungan Lapangan untuk Menanamkan Kepedulian terhadap Lingkungan Hidup. Pedagogia: Jurnal Pendidikan, 5(1), 67-80.

Zed, M. (2008). Metode Penelitian Kepustakaan. Jakarta: Yayasan Obor Indonesia. 